\title{
Küreselleşme Sürecince Avrupa Birliği'nde Belge Yönetimi Uygulamaları ve Türkiye
}

\author{
Records Management Practices in the Course of \\ Globalization in European Union and Turkey
}

\section{Özgür KÜLCÜ*}

\begin{abstract}
Öz
Çalışmada 90'lı yıllarla birlikte hız kazanan küreselleşme süreci, bu sürecin uzantısı olarak Avrupa Birliği (AB) içerisinde belge ve arşivcilik alanlarına yönelik uygulamalar ele alınmaktadır. Bu noktada belge ve arşiv yönetimine dönük olarak $A B$ bütünleşme süreci ile ortaya çıkan düzenlemeler, girişim, proje, uygulama modelleri ve standartlar tanıtılmakta ve değerlendirilmektedir. Giderek sürecin bir parçası olarak ülkemizde, belge ve arşiv uygulamalarının $A B$ açısından geliştirilmesine dönük yaklaşımlar değerlendirilmektedir.
\end{abstract}

Anahtar sözcükler: Belge yönetimi, Arşivler, Avrupa Birliği, Küreselleşme, Standartlaşma, Türkiye.

\begin{abstract}
The practices being realised in records and archive management in European Union during the accelerated globalisation after 1990's was examined. In that respect entrepreneurial initiatives, projects, regulations, practice oriented models and standards, which appeared in the course of EU integration of Turkey were overviewed. Moreover, the approaches of the EU in the realm of the European integration process, which may have chances to effect the development of records and archival practices in Turkey, were discussed and evaluated.
\end{abstract}

Keywords: Records management, Archives, European Union; Globalization, Standardization, Turkey.

\section{Giriş}

Küreselleşme, farklı ülkeler arasındaki ekonomik ve sosyal ilişkilerin diğerlerine bağlı olduğu bir işbirliği ve ortak kalkınma anlayışı olarak, izlerini yüzyılımızın ortalarından itibaren görmeye başladığımız bir yeniden yapılanma anlayışı sürecidir. Bu sürecin etkisi toplumsal hayatın her yönünde

\footnotetext{
*Dr.; Hacettepe Üniversitesi Edebiyat Fakültesi Bilgi Belge Yönetimi Bölümü 06532 Beytepe Ankara (kulcu@hacettepe.edu.tr).
} 
olduğu gibi yönetim yaklaşımlarında da gözlemlenmektedir. Genel olarak 20. yüzyılın ortalarından itibaren yönetim anlayışında gözlenen değişimi, kişilerden çok sisteme, anlık kararlardan çok kapsamlı düzenlemelere, katı disiplinden çok kaliteye, sözlü kültürden çok yazılı kültüre ve kapalı örgütlerden açık örgütlere doğru yönelim olarak özetlemek mümkündür. Yine aynı dönemde belge yönetimi disiplininin gelişimini gözlemlemek şaşırtıcı değildir. Yürütülen faaliyetler sonucu üretilen belgeleri kültür mirasının bir parçası ya da yasal delil niteliğinden ötürü saklama eğiliminde olan geleneksel arşivciliğin çalışma alanını, depolardan belgelerin üretildiği alanlara taşıması, belge yönetiminin ortaya çıkışına zemin hazırlayan unsurlar arasında sayılabilir. Öte yandan yönetimin, artan bilgi gereksinimi ve daha da karmaşıklaşan ilişki ve iletişim modelleri içerisinde, belgelere yönelik sistemli düzenlemelere duyduğu gereksinimin, belge yönetiminin gelişiminde önemli bir rolü olduğu düşünülmektedir. Giderek hızlanan değişim ve bütünleşme rüzgârında belge yönetiminin, önemini kaybeden değil önemini ve çalışma kapsamını genişleten, hatta kendilerini belge yöneticisi olarak adlandıranların dahi, zaman zaman alanın dışında kalmalarına yol açacak kapsama ulaşması dikkat çekmektedir.

Günümüzde belge yönetimi çalışmalarının, küreselleşme ve iletişim olanaklarının artışından ciddi biçimde etkilendiğinden söz edilebilir. Küreselleşme her alanda olduğu gibi belge yönetimi çalışmalarını da derinden etkilemekte ve ortak çalışmaların yapılmasını zorunlu kılmaktadır. İletişim olanaklarının artışı ise, belge yönetimi alanında gerçekleştirilen teorik çalışmaların ve uygulamaların daha geniş kitlelere son derece hızlı biçimde ulaşmasına olanak sağlamaktadır. Bu etkenlerle belge yönetimi alanında uluslararası düzenlemelere duyulan gereksinimi artırmakta ve geliştirilen standartların kısa sürede yaygınlaşması olanağını sağlamaktadır.

Küreselleşme sürecinin en önemli yapı taşlarından Avrupa Birliği (AB), etkinliği ve faaliyet alanını 1990'lı yıllarla birlikte hızla genişletmiş, pek çok alanda olduğu gibi belge yönetimi alanında da ciddi girişimlerin ve ortak çalışmaların yürütüldüğü bir platform durumuna yükselmiştir. $A B$ sürecinin belge yönetimine etkisini üç yönden değerlendirmek mümkündür. Öncelikle, AB'nin ortaya koyduğu yasal ve idari uygulamalar için uyum sürecinin gerektirdiği kurumsal yeniden yapılanma süreci, belge işlemleri ve belge yönetimi çalışmalarını etkilemektedir. İkinci etki, AB çatısı altında belge yönetimi alanında geliştirilen uygulama modelleriyle ortaya çıkmaktadır. Üçüncü etki, $A B$ çerçevesinde kültürel mirasın bir parçası olarak değerlendirilen, farklı ülkelere ait belgesel kaynakların ortak kullanımına dönük oluşturulan proje ve uygulamalar aracılığıyla gerçekleşmektedir. 


\section{Avrupa Birliği'nin Gelişimi}

1957 yılında altı Avrupa ülkesinin bir araya gelmesiyle oluşan Avrupa Ekonomik Topluluğu (AET), 1992 yılında Avrupa Birliği (AB) adını almıştır. Genişleme perspektifini giderek artıran ve sınırlarını genişleten $A B$ ekonomik, siyasi, sosyal ve hukuksal bir oluşuma dönüşmüştür. Halen 25 ülkenin üye olduğu $A B$, içlerinde Türkiye'nin de yer aldığı 4 aday ülkeyle (Bulgaristan, Romanya, Türkiye, Hırvatistan) müzakereleri sürdürmektedir (Türkiye Avrupa Birliği Karma Parlamento Komisyonu 2006).

Günümüzde $A B$ 'nin kendi yasama, yürütme ve yargı organları vardır ve uluslar üstü kurumlarıyla pek çok alanda üye hatta aday ülkeler üzerinde etkinliğe sahiptir. Bu kurumlar arasında Avrupa Birliği Konseyi (Council of Europe) AB'nin en yüksek politik organı, Avrupa Birliği Bakanlar Konseyi (The Council of Ministers) yasama ve karar alma organı, Avrupa Birliği Komisyonu (The Commission) yürütme organı, Avrupa Parlamentosu (The European Parliament), yasama ve yürütme faaliyetlerinin denetim organıdır. Avrupa Sayıştayı (The Court of Audits), gelir ve harcamaların denetimi için kurulmuştur. Avrupa Adalet Divanı (The Court of Justice) birlik antlaşmalarının uygulanması ve yorumlanmasına yönelik çalışmalar yürütmektedir (Akçeken, 2003, ss. 24-29; Coşkun, 2001, ss. 121-131; Özcan, 1999, ss. 49-52).

Yukarıda sıralanan temel organların yanında pek çok alt çalışma kollarına sahip AB kurumsal yapısı, Napolyon'dan günümüze "Tek Avrupa" düşünü gerçekleştirerek, günümüz rekabet koşullarında çok yönlü ama ortak bir güç olabilmenin yollarını aramaktadır.

Tek Avrupa düşü hayata geçirilirken bütünleşmenin öncelikle hedeflendiği üç alan ön plana çıkmaktadır. Yeni bilgi ve teknoloji üretimi, yönetsel ve idari sistemlerin uyumluluğu, kültürel mirasın korunması ve buna bağlı olarak ortak kültür kimliğinin oluşturulması $A B$ sürecinin öncelikli hedefleri arasındadır. Bu üç alan doğrudan belge ve arşiv çalışmalarıyla oldukça yakından ilişkilidir. İlerleyen bölümlerde ifade edileceği gibi, elektronik iletişim ve e-ticaret uygulamalarının elektronik belge yönetimi rehber modelleri ve standartları olmadan yürütülmesi mümkün değildir. Kurumlar için giderek vazgeçilmez hale gelen ve yönetsel faaliyetlerin de oldukça önemli bir bölümünün yürütüldüğü elektronik ortama yönelik bütünleşik sistemlerin geliştirilmesi, bugün AB'nin öncelikli hedefleri arasındadır. Bir diğer önemli konuyu yönetsel ve idari uyumluluk oluşturmaktadır. $A B$ süreci kapsamında, binlerce sayfadan oluşan ve hemen hemen yaşamın her alanına ilişkin düzenlemeler olduğu bilinmektedir. Kurumlarda belge ve arşiv çalışmalarının önemli bir bölümünü, idari ve yasal gereklilikler doğrultusunda kurumsal iletişim, doğrulama ve onay faaliyetleri oluşturmaktadır. Belge ve arşiv çalışmaları idari ve yasal gerekliliklere uygun ve olmak durumundadır. İdari 
ve yasal koşullardaki değişimler doğrultusunda belge işlemlerinin yeniden düzenlemesi ve eşgüdümleşmesi oldukça önemlidir. $B u$ çerçevede $A B$ sürecinde belge ve arşiv çalışmalarının yeni oluşan idari ve yasal çerçevede tanımlanması ve uygun programların geliştirilmesi gerekmektedir. Ortak kültür yaklaşımı ve geçmişe dönük kültürel mirasın korunması $A B$ çerçeve programlarının öncelikli hedefleri arasında sıralanmaktadır. Günümüzde $A B$ çerçevesinde geliştirilen projeler içerisinde, $A B$ üst kimliğinin oluşumu ve geniş kesimlerce benimsenmesinin aracı olarak arşiv, müze, kütüphane gibi bu mirasın taşıyıcısı konumundaki kurumların desteklenmesi ve kullanımına dönük bütünleşik yaklaşımlar oldukça popülerdir. Bu çerçevede yazılı tarih kalıtı olan arşivlerin ortak kullanımı, AB sürecini destekleyen en önemli araçlardan biri konumundadır.

\section{Avrupa'da Belge ve Arşiv Çalışmalarının Geçmişine Kısa Bir Bakış}

Belgelerin arşivlere gelmeden üretim aşamasından başlanarak denetimine dayalı belge yönetimi yaklaşımının, ABD Ulusal Arşivinin kuruluşu ile gündeme girdiği, sonrasında Hoover Komisyonu çalışmalarıyla yaşam döngüsü çerçevesinde tanımlandığı bilinmektedir. Yeni Kıta'da ortaya çıkan yaklaşımın, uzunca bir süre Eski Kıta Avrupa'ya etkisi zayıf kalmıştır. Avrupa'da ilk kez 50'li yıllarda Ingiltere'de belge yönetimi çalışmaları başlamış, 90'। yıllarla birlikte AB'nin de etkisiyle çalışmalar ivme kazanmıştır (Cook, 1986, s. 53; Doug, 1996, ss. 212-214; Penn, 1994, s. 5).

Öte yandan köklü bir tarih ve kurumsallaşma kültürü olan Avrupa ülkeleri, arşiv ve arşivcilik tarihi açısından son derece zengin bir geçmişe sahiptir. 1789 Fransız Devrimi ile başlayan, sanayileşme süreci ile gelişen ulusal devletler ve bu devletler içerisinde şekillenen kurumsal işletmeler, yeniden düzenlenen yasal ve yönetsel yapılarına uygun belgeleri üretmiş ve kullanmışlardır. Devrim ile birlikte Fransa'daki ilk gelişmelerden birisi, Fransız Ulusal Arşivi (Archives Nationales)'in kurulması olmuştur. Fransız Ulusal Arşivi, çalışma kapsamına resmi nitelikteki tüm kurumları alarak, arşiv çalışmalarında eşgüdüme gidilmesi için ortak programlar geliştirilmesine çalışmıştır. Bu gelişmelerin peşinden 1838 yılında İngiliz Devlet Arşiv Yasası (British Public Record Office Act)'nın çıkarıldığına tanık oluyoruz (Bradsher, 1988, ss. 25-28; Eden ve Feather, 1997, s. 3). Osmanlı Devleti ulusal arşivi niteliğindeki Hazine-i Evrak'ın kurulması çalışmaları, 1845 yılında başlatılmış ve 1849 yılında Hazine-i Evrak'a ilişkin ilk nizamname yayımlanmıştır (T.C. Başbakanlık Devlet Arşivleri Genel Müdürlüğü Osmanlı Arşivleri Daire Başkanlığı, 2000). Yüzyılın başında Almanya'da Friedrich Meinecke ilk kez arşivlerde alıkoyma ve düzenleme programlarını dile getirmiştir. Meinecke'nin ortaya koyduğu ilkeler, kısa zamanda Almanya'da resmi yazışmaların düzenlenmesini belirleyen yasal uygulamalara dönüşmüştür. 
Provenans ve organik düzenlemeye dayanan ve Meinecke'nin yaklaşımının öncülüğünde yasal çerçeveye kavuşan uygulamalar, uzun yıllar belge ve arşiv çalışmalarını belirleyen ilkeler olarak kabul edilmiştir. Öte yandan İngiltere'de 1950 tarihinde yayımlanan Grigg Raporu ve 1981'de bu raporun geliştirilmesiyle oluşturulan Wilson Raporu, İngiliz Ulusal Arşivi (British Public Records Office) ve UNESCO'nun ortak çalışmalarının bir ürünüdür. Bu raporlarda, belge ve arşiv çalışmalarına yönelik genel bir çerçeve çizilirken, bazı ölçütler üzerinde durulmaktadır. Bu ölçütler genel olarak; "tarafsızlık", "herhangi bir kullanıcı grubunun özelliğine değil tüm kullanıcı kitlesinin beklentileri düşünülere hizmet ilkelerinin belirlenmesi", "objektiflik", "işlemleri yürüten personelin kişisel eğilimlerinin yürüttüğü çalışmalara yansıtılmaması", "profesyonellik", "arşiv çalışmalarını yürütecek personelin arşivist kimliğine sahip uzman kişilerden oluşmasının sağlanması" vb. olarak sıralanmaktadır. Yine belge ve arşiv çalışmalarının başarısı için, bu çalışmaları etkileyen ya da belirleyen tüm kurumsal yapının analiz edilmesi, arşiv öncesi belge çalışmaları ve arşiv çalışmalarında uygulanacak yasal işlemlerin bu çerçevede oluşturulması, raporlar içerisinde değinilen konular arasındadır (Cook, 1986, s. 52; UNESCO, 1987, s. 5).

Avrupa'da, uzunca bir süre belge yönetimini arşiv alt alanında tanımlama eğilimi görülmüştür. İngiltere'de 1950'li yılların sonlarından itibaren bölgesel anlamda hizmet veren belge büroları (records offices) görevlerini, güncel belgelerden güncel olmayanların ayıklanarak arşive nakline karar vermek olarak tanımlamışlardır. Dağınık biçimde çalışmalarını yürüten bu bürolar 1968 yılında, Arşivciler Derneği'ne (Society of Archivists) bağlı Belge Yönetim Grubunun (Records Management Group) çatısı altında toplanmış ve çalışmalarını 1977 yılına kadar devam ettirmişlerdir. İngiltere'de belge yönetimine dönük yeni bir yaklaşım olarak ortaya çıkan oluşum, 1987 yılında kurulan Büyük Britanya Belge Yönetimi Derneği'dir (Records Management Society of Great Britain). Dernek, pek çok yayın faaliyetini de yürütmektedir. Bu yeni oluşumu ayıran en temel fark, belge yönetimini bağımsız bir disiplin olarak, arşiv çalışmalarının dışında değerlendirilmesi savını büyük ölçüde savunuyor olmasıdır (Cook, 1993, s. 27).

\section{Avrupa Birliği Süreci ve Belge Yönetimi Çalışmaları}

$A B$ sürecinin belge yönetimi çalışmalarının gelişimine etkisi açısından, önceleri ulusal düzeyde zamanla $A B$ çerçevesinde geliştirilen yasal düzenlemelerin üzerinde durulmasında yarar vardır. Bu çerçevede "Veri Koruma Yasası" adı altında geliştirilen düzenlemeler dikkat çekmektedir.

Avrupa'da ilk Veri Koruma Yasası (Data Protection Act) 1973 yılında İsveç'te kabul edilmiştir. Bu yasa belge yönetimi ve belge koruma 
çalışmalarını doğrudan etkilemiştir. Geliştirilen düzenleme, yurttaşların elektronik ya da basılı formatta belgelere serbest erişimine imkân sağlamış ve bilginin mahremiyeti hakkında ilkeleri ortaya koymuştur. Avrupa Konseyi Veri Koruma Konvansiyonu'nun (European Commission's Data Protection Convention) 1981 yılında gerçekleştirdiği ilk toplantıda alınan kararların ardından, pek çok Avrupa ülkesinin kendi ulusal veri koruma yasalarını hazırlamışlardır. 90'lı yıllarla birlikte içerlerinde Almanya, Avusturya, Belçika, Danimarka, Hollanda, Lüksemburg ve Norveç'in de bulunduğu pek çok Avrupa ülkesi, benzer yasal düzenlemeler yapmışlardır. Öte yandan çıkartılan veri koruma yasalarının İngiltere, İspanya ve Portekiz'in de yer aldığı bazı Avrupa ülkelerinde, anayasal güvenceye alındığı dile getirilmektedir. Geliştirilen düzenlemeler içerisinde 1984 tarihinde İngiliz Parlamentosu tarafından kabul edilen Veri Koruma Yasası'nın, belge yönetimi çalışmalarına oldukça ayrıntılı biçimde yer verdiği ifade edilmektedir (Data Protection Act, 1998; Stephens, 1998, s. 73). Avrupa genelinde veri koruma yasası adı altında kabul edilen düzenlemelerde aşağıdaki başlıklar üzerinde durulmaktadır:

$>$ Yasal düzenlemeler genel olarak üretilen bilgi ve belge kaynaklarına serbest erişimi, bunların açıklanması ve yönetimine dönük ilkeler ele almaktadır.

$>$ Bazı ülkelerdeki yasal düzenlemeler sadece kamu kesimini kapsarken, kimi düzenlemeler kamu ve özel kesimin tamamını içine almaktadır.

$>$ Düzenlemelerde bilginin güncelliği ve yenilenebilirliği özellikle vurgulanmaktadır.

> Çıkartılan düzenlemelerde bilgiye izinsiz erişimin engellenmesi amaçlanmaktadır.

> Düzenlemelerin tamamına yakınında, kişilerin kendileri hakkında tutulan kayıtlara erişiminin önündeki engellerin kaldırılması dile getirilmektedir. Yine bu kapsamda yanlış ya da eksik tutulan bilgilerin düzeltilmesi talebinde bulunma hakkı ve gereği konusundaki yaptırımlar vurgulanmaktadır (Stephens, 1998, s. 74).

Bu kapsamda AB'de, birlik içerisinde bilginin serbest dolaşımı üzerine bir yönetmelik hazırlanmıştır. Bu yönetmelikte genel olarak aşağıdaki unsurlar üzerinde durulmaktadır:

> Yönetmelik ortamı ne olursa olsun kişisel bilgilerin yer aldığı tüm kaynakları kapsamaktadır.

- Kişisel bilgilere, yapılandırılmış formatlarıyla belgelere, kolay erişim sağlamak için dosyalama sistemlerinin geliştirilmesi gerektiğine değinilmektedir. 
> Yönetmelikte organizasyonların ve veri işleyen kurumların; kişilerin etnik kökeni, politik duruşu, dini inançları ve ticari ilişkileri hakkında bilgi toplaması yasaklanmaktadır.

$>$ Bazı ülkelerdeki düzenlemeler gibi, kişilerin kendileri hakkında tutulan bilgilere erişim için var olan sisteme herhangi bir üyelik kaydı yapmalarına gerek olmadığı, böyle bir istek geldiğinde ilgili kurumun bunu doğrudan değerlendirmeye alması gerektiği üzerinde durulmaktadır.

- AB tarafından çıkartılan Yönetmelik, kişisel verilerin sadece kullanımı değil, üzerinde yürütülen tüm çalışmaları kapsamaktadır. Yönetmelik veri işleme, sağlama, kaydetme, organizasyon, depolama, erişim, danışma, kullanım, yayım ya da gerekliyse imha uygulamalarını içine almaktadır (Stephens, 1998, s. 75).

Öte yandan $A B$ içerisinde bazı ülkeler, kendi gereksinimleri doğrultusunda özellikle elektronik belge ve arşiv çalışmalarına dönük çeşitli uygulamalar gerçekleştirmişlerdir. Oldukça güncel olan çalışmalar $A B$ açısından elektronik belge yönetimi konusunda artan ilginin bir göstergesidir. Aşağıda bu çalışmalara ülke perspektiflerinden çeşitli örnekler sunulmaktadır.

Almanya'da e-Avrupa çalışmalarını destekleyen ulusal program, BundOnline 2005 olarak adlandırılmaktadır. Kamu kesiminde e-devlet çalışmalarını doğrudan federal hükümetler yönlendirmektedir. Alman hükümeti kısa adı DOME (Document Management and Electronic Archival) olan Doküman Yönetimi ve Elektronik Arşivler Standardını oluşturmuştur. DOME Standardı'nın elektronik belge yönetimi çalışmalarının tüm yönlerini ele alan oldukça kapsamlı bir düzenleme olduğu üzerinde durulmaktadır. DOME genel olarak üç başlıkta ele alınmaktadır.

1. Belge Kayıt Sistemi (Records Registry System): Elektronik belge yönetimi çalışmalarında kullanılacak bir gömü (thesaurus) ve hiyerarşik düzenden oluşan yapıyı ortaya koymaktadır.

2. Elektronik Dosya Sistemi (Electronic Folder System): Kâğıt ortamdaki belgelerin de dâhil olduğu, bir olay ya da kişiye ait tüm dokümanlara yönelik arşiv ve doküman yönetim sistemini, çevresel unsurlarla birlikte kapsamaktadır.

3. İs Süreç Yönetimi (Business Processes Management): Kurumsal iş akışının, elektronik ve elci olarak tüm boyutlarıyla ele alındığı bütünsel bir sistemi ortaya koymaktadır (Waldron, 2004, s. 35).

Fransa'da uzunca bir süre elektronik belgelerin güvenilirliği sorun olarak algılanmıştır. Ancak son dönemlerde elektronik belgelerin delil niteliğini onaylayan yasal düzenlemeler gerçekleştirilmiştir. Fransız ulusal standartları içerisinde yer alan NF Z 42-013 elektronik belgelerin uyumluluğu üzerine 
düzenlemeleri içermektedir. İlgili düzenlemeyi esas olarak ISO'nun, Fransız Ulusal Standartlar Örgütü AFNOR ile birlikte Elektronik Veri Depolama Standardını geliştirme çalışmalarını başlattığına değinilmektedir (Waldron, 2004, s. 34).

Hollanda diğer Avrupa ülkelerini takip ederek, kamusal alanda iş ve işlemlerin yüzde 25'nini elektronik ortama taşımayı başarmıştır. Elektronik Devlet İcin Eylem Programı (Action Program for Electronic Government) adıyla yürütülen çalışmalar, yerel ağ altyapısının geliştirilmesi ve güvenli haberleşme gibi özellikle altyapıya yönelik iyileştirmeyi amaçlamaktadır. Bu kapsamda elektronik belge koruma, elektronik alt yapı çalışmalarının ayrımaz bir parçası olarak değerlendirilmektedir. İlgili çalışmaların Ulusal Arşiv ve İçişleri Bakanlığının ortak bir projesi çerçevesinde yürütüldüğüne değinilmektedir (Waldron, 2004, s. 32).

İngiltere'nin 2004'de kabul ettiği Devletin Modernizasyonu Raporu (White Paper on Modernizing Government) çerçevesinde, 2005 yılı sonu itibariyle tüm kamu kurumlarında merkezi idarelerce üretilen belgelerin sadece elektronik belgelerden oluşması, merkezi ve yerel kamu hizmetlerinin tümünün çevrimiçi olarak da gerçekleştirilmesi öngörüsü (Waldron, 2004, s. 32) hayata geçirilmiştir.

Gelişen koşullar değerlendirildiğinde, e-devlet ve e-iş çözümlerinin büyük ölçüde iletişim, haberleşme, bilgi akışı gibi alanlarda hızlı, etkin ve güvenilir sistemleri amaçladığı görülmektedir. Bu noktada belge yönetimi ve özelikle elektronik belge yönetimi, çalışmaları ilgili amaçları destekleyen en önemli araçlardan biri konumundadır.

Avrupa'da belge yönetimi çalışmaları Kuzey Amerika'da ya da Avustralya'da olduğu gibi uzunca süre güncel iş sürecinin bir parçası olarak değil, arşiv çalışmalarının uzantısı olarak değerlendirilmiştir. Ancak 2000'li yıllarla birlikte teknoloji, $A B$ ve meslek derneklerinin de etkisiyle koşullar değişmeye başlamıştır. Bu değişimde aşağıdaki gelişmeler etkili olmuştur:

> E-ticaret ve elektronik imza üzerine Avrupa Komisyonu yönetmelikleri (directories), özel ve kamu kesiminde elektronik belge yönetimi sistemlerine duyulan gereksinimin artması.

- Avrupa Komisyonu, Uluslararası Arşiv Konseyi (International Archival Council; ICA) meslek dernekleri ve ilgili diğer kurumların ortak çalışmaları.

$\mathrm{Bu}$ noktada, $\mathrm{AB}$ genişleme politikaları içerisinde arşiv yönetimi çalışmalarına özel önem gösterilmesi kararı alınmıştır. E-Avrupa girişimine katılan ülkelerin, kamu yönetiminin modernizasyonu ve e-iş çözümleri üzerine odaklandıkları dikkat çekmektedir. 90'ı yılarda Avrupa'daki ülkelerin kendi gereksinimleri doğrultusunda hazırladığı elektronik ortamda belge yönetimi 
çalışmalarını tanımlayan düzenlemeler, AB'nin etkinlik alanını genişletmesiyle, $A B$ düzenlemelerine dönüşmeye başlamıştır. Bu kapsamda belge ve arşiv çalışmalarını doğrudan ilgilendiren;

$>$ Elektronik kontratlarda e-Ticaret Yönetmeliği,

- Dijital imzayı yasallaştıran Dijital İmza Yönetmeliği,

> Elektronik bilgi ve doküman yönetimi üzerine Elektronik Veri Değişim Yönetmeliği (Electronik Data Interchange Directive),

$>$ Bilgiye serbest erişim üzerine Bilginin Serbestliği Yasası (Freedom of Information Act),

- Kişisel bilgilerin korunması ve değerlendirilmesi üzerine Veri Koruma Yasası (Waldron, 2004, s. 31) çıkartılmış ve uygulamaya konulmuştur.

$A B$ yeni yüzyılda hızlı biçimde sayısallaşmaya yönelmektedir. Bu durumun en yoğun etkisini, daha önce kâğıt üzerinde gerçekleşen çalışmaların elektronik ortamda yürütülmeye başlamasında görmek mümkündür. Günümüzün elektronik ortamı etkili ve hızlı iletişim için vazgeçilmez görülmektedir. Yeni koşulların yasal alt yapısının hazırlanması ve uygulama problemlerinin çözümünde elektronik iletişim ve belge yönetim programlarına duyulan gereksinim artmaktadır. Günümüzde elektronik depolamanın klasik depolamaya göre daha ucuz hale gelmesi ve depolama kapasitesinin her yıl iki katının üzerinde artması gibi etkenlerle birlikte (Spratt, 2003, s. 9), sayısallaşma sürecinin artarak süreceğini söylemek mümkündür.

$A B$ içerisinde e-ticaret ve e-devlet çalışmalarının bir parçası olarak oluşturulan İdareciler Arasında Veri Değişimi Girişimi (Interchange of Data Between Administration; IDA) aynı zamanda, $\mathrm{AB}$ içerisinde elektronik belge yönetimi alanında ciddi çalışmaların öncülüğünü yapmıştır. IDA, 1996 yılında ilk kez düzenlenen DLM Forumunu* (Document Lifecycle Management Form; Doküman Yaşam Döngüsü Yönetimi Forumu) desteklemiştir (Cain, 2003, s. 54). DLM Forumu, zamanla Avrupa Komisyonu içerisinde belge yönetimi alanında bağımsız çalışmaların yapılmasına olanak sağlamıştır.

Forumun oluşturulması çalışmalarının 1991 yılına kadar uzandığı dile getirilse de Avrupa Komisyonu'nun 1996 yılında Brüksel'de yaptığı toplantı sonucunda resmiyet kazanmıştır. Forum içerisinde kamu ve özel kesimden belge ve arşiv yöneticileri, kamu yöneticileri ve bilgi teknolojisi uzmanları yer almaktadır. Forum genel olarak belge yönetimi, elektronik doküman ve belgeler ile arşiv hizmetleri arasındaki ilişkiyi sorgulamaya yönelmektedir. Forum çerçevesinde ayrıca ICA öncülüğünde geliştirilen düzenlemelerin Avrupa boyutunda tartışması amaçlanmaktadır (MacKenzie, 1999, s. 31).

\footnotetext{
* Başlangıçta adı 'Donnes Lisibles par Machine'in kısaltmasından gelen forum, -Fransızca makinece okunabilir veri demektir- zamanla 'Document Lifecycle Management Form'un kısaltmasına dönüşmüştür -Doküman Yaşam Döngüsü Yönetimi Forumu-)
} 
DLM içerisindeki çalışmalar, üyeler birlikte aday ülkeleri de kapsayacak şekilde genişlemiştir. 1999 yılında ortaya çıkan MoReq Standardı, DLM Formu'nun bir ürünü olarak değerlendirilmektedir. Öte yandan AB Konseyinin 2003 yılında düzenlediği, devlet başkanlarının katılı̆̆ı Arşivler Üzerine Çözüm Toplantısı'nda (Resolution on Archives), iyi korunmuş ve erişilebilir arşivlerin toplumun demokratikleşmesine hizmet etmesi üzerinde durulmuştur (Waldron, 2004, s. 32).

Elektronik belgeler üzerine Avrupa Komisyonu'nun aldığı kararla oluşturulan DLM Forumu çerçevesinde, günümüze değin oldukça geniş kapsamlı çalışmalar yürütmüştür. Forumun öncelikli hedefleri arasında yer alan; elektronik belgelerin yönetimi, ilgili konuda Avrupa ülkelerinin bilgilendirilmesi ve bir elektronik belge yönetimi rehberi oluşturma çabaları $A B$ için oldukça önemli sorunlar arasında sayılmaktadır. DLM Forumu ile Avrupa boyutunda elektronik belge yönetime dönük çok disiplinli ortaklıklar oluşturmak ve konu ile ilgili Avrupa ülkeleri arasında karşılıklı bilgi akışını sağlamak amaçlanmaktadır. Forum $A B$ içerisinde elektronik belgelerin yönetimine dönük en önemli girişim olarak tanımlanmaktadır (Donnes Lisibles par Machine [DLM], 1999; Stephen, 2001, s. 66). Ayrıca bu girişimler çerçevesinde Information Summary on Archives (INSAR) ve European Archives News adlı iki süreli yayın yayımlanmaktadır (MacKenzie, 1999, s. 31). Forum çerçevesinde Avrupa'da e-devletin desteklenmesi, ilgili alanda son gelişmelerin yakalanması, elektronik ortamdaki bilgi ve belgelere erişimin mevcut durumu, sorunlar ve bunların çözümüne yönelik oldukça kapsamlı araştırma raporları yayımlanmıştır (Cain, 2003, s. 54). Bu noktada 2002 tarihinde INSAR tarafından konferans bildirileri şeklinde yayına dönüştürülen, $A B$ çerçevesinde bilgi, belge ve doküman yönetimi üzerine bilimsel yaklaşımlardan oluşan 648 sayfalık çalışma oldukça önemli görülmektedir. DLM Forumu Organizasyon Komitesi'nce hazırlanan çalışma aşağıdaki başlıklarda ayrıntıı bilgiler içermektedir:

$>A B$ çerçevesinde elektronik belge yönetimi çalışmaları ve üst veri unsurları,

> Belge koruma, iletişim ve uzun dönem saklama koşullarını tanımlanması,

> Sayısal ortamda bilimsel ve teknik belgelere yönelik işlemler,

> Değişen koşullarda belge ve arşiv uzmanlarının yetiştirilmesine dönük eğitim notları,

> Otomatik indeksleme teknolojileri ve erişim çözümleri,

> Belgelere yönelik üst veri standartlarının oluşturulması ve uygulanması,

- Dijital imzanın kullanımı ve uygulamalar,

- Sayısal kayıtların yasal koşullarının tanımlanması (INSAR, 2002). 


\section{AB İçerisinde Belge ve Arşiv Çalışmalarına Yönelik Sürdürülen Girişim ve Projeler}

$A B$ içerisinde belge ve arşivcilik alanlarındaki gelişmelerin istenilen düzeye ulaşmadığı dile getirilse de (Stephens, 2001, s. 66), belge yönetimine yönelik olarak sürdürülen girişim ve projeler söz konusudur. Bu çalışmaların çıkış noktası olarak, AB'nin İnternet, e-ticaret ve bilgi teknolojisi alanlarında ABD'nin gerisinde kalması karşısında, öncelikle gerekli altyapı unsurlarında iyileştirmeler yapmaya yönelmesi gösterilmektedir.

$A B$ ülkelerinde belge yönetimi alanında faaliyet gösteren dernekler, ulusal arşivler ve çeşitli kurumlarca geliştirilen ya da doğrudan desteklenen projeler ve rehberler, uluslararası alanda bilgi ve belge yönetimi uygulamalarının geliştirilmesine ışık tutacak niteliktedir. Çok çeşitli alanlarda oluşturulan bu çalışmalara aşağıdaki örnekler verilebilir.

AB Arşiv Ağı (European Union Archive Network - EUAN).

Avrupa Komisyonu Info2000 Girişimi tarafından yürütülen Proje'nin amacı, $A B$ içerisinde arşivlere serbest erişimi mümkün kılmaktır. Proje, $A B$ içerisinde yer alan ülkelere ait ulusal arşivlerin içeriğine yönelik bilgileri yurttaşların kullanımına sunmaktır. 1999'da başlanan projeye İtalya, İskoçya ve İsveç arşivleri doğrudan katılmaktadır. AB bütçesinden Projeye 0,4 milyon Avroluk destek sağlanmıştır (European Union Archive Network [EUAN], 2003).

AB E-İcerik Programı (European Union E-Content Programme).

$A B$ e-Içerik Programı, Avrupa sayısal bilgi içeriğinin üretimi, yayımı ve kullanımını desteklemek amacıyla oluşturulmuştur. Proje kapsamında oluşan içeriğin, farklı dillerde çevirisine yönelik çalışmalar da yürütülmektedir. 2000 yılında başlayan proje 2001-2005 yıllarını kapsamaktadır. Proje bütçesi olarak AB tarafından 100 milyon Avroluk kaynak tahsis edilmiştir. (European Union [EU], 2005). E-içerik Programının Türkiye'deki temas noktasını Devlet Planlama Teşkilatı oluşturmaktadır. Program tarafından sağlanan mali yardımlarla başta KOBi'ler olmak üzere sayısal içerik pazarında yer alan kuruluşlar desteklenmektedir (Türkiye Bilişim Derneği, 2006, s. 39).

\section{Açık Toplum Arşivleri Girişimi (Open Society Archives)}

Açık Toplum Arşivleri Girişimi, II. Dünya Savaşı sonrasında özellikle Doğu Avrupa ülkelerine yönelik araştırma ve kaynak gereksinimini karşılamak üzere oluşturulmuştur. Doğu Avrupa üniversitelerinin belge ve arşiv çalışmalarını düzenlemek girişimin amaçları arasındadır. Şu anda Merkezi Avrupa Üniversitesi (Central European University) içerisinde hizmet vermektedir. Çoğunluğu Doğu Avrupa ve Rusya kaynaklarından oluşan $3000 \mathrm{~m}^{2}$ alanı kaplayan bir arşiv koleksiyonu vardır ve Soros Vakfı tarafından desteklenmektedir (Central European University, 1995-2000). 
Arşiv Kaynaklarının Korunması Üzerine Kaynak ve Bilgi Geçidi (Gateway for Resources and Information on Preservation - GRIP)

Arşiv Kaynaklarının Korunması Üzerine Kaynak ve Bilgi Geçidi, AB'nin dokümanter geçmişinin korunması üzerine gerekli bilgilerin yer aldığı bir ortam olarak geliştirilmiştir. Oldukça zengin bir kaynak arşivine sahip GRIP üzerinde tarihi bilgi ve belge kaynaklarının korunması ile ilgili web siteleri, proje, organizasyon ve tartışma gruplarına erişmek mümkündür. Portal yapısı, Hollanda Ulusal Arşivi (The National Archives of the Netherlands) ve Koruma ve Erişim Üzerine Avrupa Komisyonu (European Commission on Preservation and Access, ECPA)'nun girişimleri sonucunda kurulmuştur ve faaliyetlerini hâlihazırda sürdürmektedir (European Commission on Preservation and Access, 2004).

Avrupa Arşiv Ağı (European Archival Network - EAN)

EARN, Avrupa'da yer alan tüm arşivlere erişim için hazırlanmış bir arşiv portalı niteliğindedir. 1998'de İsveç'te düzenlenen Avrupa Arşiv Zirvesi (European Summit on Archives)'nin aldığı kararla kurulmuştur. Merkezi Berne'dedir Portal içerisinde sunulan harita yardımıyla, Avrupa arşivlerine alfabetik ya da coğrafi tarama ile erişim mümkündür. EAN'ın çalışmaları ICA Avrupa Temsilciliği (European Board of ICA) tarafından yürütülmektedir. İsveç Federal Arşivleri (Swiss Federal Archives) portalın web yöneticisi konumundadır. Portalın amaçları;

- Avrupa arşivlerine yönelik bilgi portalı olmak,

> Avrupa arşivlerine yönelik bir tarama merkezi olmak,

> Avrupa'da ve dünyada arşivler için bir bağlantı ve değişim noktası olmak, şeklinde sıralanmaktadır (European Archival Network, 2006).

Avrupa Digital Arşiv ve Hafiza Deposu Projesi (Digital Archive and Memory Storage Project - DAMS)

Avrupa Komisyonu Avrupa Üzerinde Uziletişim Programı (Trans European Telecommunication Network; Ten Telecom Program) çerçevesinde yürütülen Proje, arşiv merkezleri ve arşiv kaynaklarından yararlanan kişilere özelleştirilmiş hizmetler ve araçlar sağlamak için, İnternet ortamında bir platform oluşturmayı amaçlamaktadır. Proje çerçevesinde, Avrupa'daki arşiv kaynaklarından İnternet ortamında uz iletişim araçları yardımıyla yararlanma konusunda çalışmalar yürütülmektedir. 2002'de başlanan ve merkezi Milano'da olan proje 2004 yılında tamamlanmıştır (Europe DAMS Project, 2006).

Avrupa Görsel Arşivi Projesi ( European Visual Archive - EVA)

Projenin amacı, görsel kültür varlıklarını daha geniş halk kesimlerinin kullanımına sunmaktır. Avrupa Birliği'nin Info2000 grubu tarafından desteklenmektedir. Proje kapsamında 1840'dan günümüze tarihi değere sahip koleksiyonlarından oluşan, yaklaşık 18.025 fotoğraf sayısal ortama aktarılmış ve kullanıma sunulmuştur (European Visual Archive, 2006). 
Avrupa Konseyi Arşivlere Erişim Gözlem Projesi (Council of Europe Access to Archives Monitoring Project)

Başlangıçta Avrupa kültürünün bir parçası olduğu düşünülen 22 ülkeye yönelik olarak 2000 yılında hayata geçirilen proje kapsamında, şu anda 48 ülke arşivlerine erişim ve ilgili arşivlere yönelik araştırma yapılabilmektedir. Proje kapsamında ilgili ülkelerde arşiv kanunları, yönetmelikleri ve uygulamaları incelenmekte ve çeşitli araştırma raporları yayımlanmaktadır. Çalışmalar sonucu ortaya çıkan öneriler, Arşivlere Erişim Üzerine Avrupa Politikaları adı altında Avrupa Tavsiye Raporu olarak yayımlanmıştır (International Council on Archives [ICA], 2003).

\section{Başlıca Kaynak Depoları Projesi (Repositories of Primary Sources)}

Belge ve arşiv çalışmalarını yürüten kişiler için hazırlanmış bir portal niteliğindedir. Portal üzerinde dünyanın çeşitli bölgelerinde yer alan yaklaşık 5300 arşiv, el yazması, nadir eser, tarihi fotoğraflar ve diğer önemli kaynakların yer aldığı siteler tanımlanmıştır. Portalın İnternet ortamında araştırma arşivlerine yönelik en kapsamlı bilgiyi içerdiği dile getirilmektedir (Tulane University, 2006). Portal üzerinde özellikle kamusal alanda hizmet veren belge, arşiv ve el yazması kuruluşlarına bağlantılar yapılmaktadır. Portal çalışmaları Idaho Universitesinden Terry Abraham tarafından yönlendirilmektedir (Abraham,1995-2006).

Comitern Arşivleri Projesi (Comitern Archives Project)

Comitern Arşiv Projesi, Rusya Ulusal Arşivi ile ICA'nın ortak girişimleriyle başlatılmış ve Avrupa Konseyi'nin doğrudan desteğiyle yürütülmüştür. Avrupa Konseyi Uluslararası Komitesine bağlı olarak Rusya, ICA ve altı eş kuruluş tarafından gerçekleştirilen, ancak istenildiği kadar fazla ortak sağlanamayan proje çalışmaları sınırlı kalmıştır (UNESCO, 2005).

Elektronik Belgelerin Yasal Koşulları Projesi (Legal Evidence of Electronic Records)

Proje, elektronik ortamda üretilen ya da kullanılan belgelerin, yasal ve tarihi açıdan delil niteliğini ortaya koyacak ölçütleri belirleme amacını taşımaktadır. ICA ile birlikte 1998 yılında başlanılan Proje, 2003 yılında tamamlanmıştır. Genel olarak elektronik ortamda belge ve arşiv yönetimine yönelik bir çerçeve çizmeyi hedefleyen Proje aşağıdaki unsurları içermektedir;

1. Belge ve arşiv yönetiminde elektronik belgelerin ne gibi değişimlere yol açtığını belirleme,

2. Uluslararası stratejilerin geliştirilmesine yönelik tavsiyeler oluşturma,

3. Elektronik belgelerin yasal koşullarını belirlemeye yönelik düzenlemeler geliştirme (UNESCO, 2004). 
Uluslararası Kütüphane Dernekleri ve Enstitüleri Federasyonu (International Federation of Library Association and Institutions - IFLA) Bilgiye Serbest Erişim ve Ifade Özgürlügü Komitesi (Committee on Free Access to Information and Freedom of Expression - FAIFE; IFLA/FAIFE).

IFLA/FAIFE, IFLA altında 1998 yılında Kopenhag'da oluşturulmuş bir girişim şeklinde, Birleşmiş Milletler Evrensel İnsan Hakları Bildirgesinin 19. maddesine dayanarak, bilgi ve belge hizmetlerine yönelik temel hakları belirleme amacıyla çalışmalar yürütmektedir. Kütüphane ve bilgi hizmetleri alanında, sorunları tespit etme ve sorunlu kurumları uyarma görevleri arasında sayılmaktadır (IFLA/FAIE, 1998).

Kamu Sektörü Belge Yönetim Projesi (Management of Public Sector Records Project - MPSR)

Uluslararası Belge Yönetimi Vakfı (International Records Management Trust; IRMT) tarafından geliştirilen, özellikle gelişmekte olan ülkelerde kamusal belgelerin yönetimi üzerine oluşturulmuştur. ARMA ve ICA'da projeye aktif destek vermektedir. Projenin temel hedefi arasında, kamu sektörü bilgi kaynaklarının yönetiminde bütünleşik projeler geliştirmek, belge ve arşiv profesyonellerine stratejik kaynaklarını yönetme konusunda destek sağlamak sıralanmaktadır* (MacKenzie, 1999, s. 25).

Kütüphane ve Arşivler İçin Sayısal Programların Oluşturulması İçin Rehber (Guidelines for Establishing Digitization Programs for Libraries and Archives)

IFLA'nın katkılarıyla 2000 yılında başlanan proje 2002 yılında tamamlanmıştır. Sosyal gereksinimlerin karşılanmasına yönelik çeşitli çalışmalar yürüten UNESCO bu proje çerçevesinde; bilginin evrensel olarak yeniden tanımlanması, özellikle kamu kesiminde bilgi kullanıcılarının hizmet gereksinimlerinin belirlenmesi ve kamu kaynaklarından etkin olarak yararlanıması konusunda hizmet ilkelerini ortaya koymayı amaçlamaktadır. Proje aşağıdaki unsurları kapsamaktadır:

$>$ Bilgi kaynaklarının seçimi

$>$ Değişim politikaları ve teknikleri

$>$ Üst veri unsurları

$>$ Yasal etkenler

$>$ Kalite kontrol

$>$ Maliyet

$>$ İnsan kaynakları yönetimi

$>$ Teknik gereksinimlerin analizi

> Web sayfaları için ara yüzlerin geliştirilmesi ve devamlılığı

$>$ Sayısal içeriğin korunması

> Proje yönetimi (UNESCO, 2002).

* Ayrıntılı bilgi www.irmt.org/download/DOCUME 1/EDUCAT 1 adresinden edinilebilir. 
UNESCO Arşiv Portalı (Unesco Archival Portal)

UNESCO Arşiv Portalı, arşivistler ve arşiv kullanıcılarına dünya çapında bir enformasyon otobanı oluşturmayı amaçlamaktadır. Portal UNESCO'nun İletişim, Bilgi ve Bilişim Sektörü (UNESCO's Communication, Information, and Informatics Sector CII) tarafından geliştirilmiştir. Dünyada yer alan belli başı arşivlere yönelik bağlantılar yanında, İnternet üzerinde yer alan arşiv kaynaklarına erişim ortamı sağlamaktadır. Portal üzerinden ayrıca, arşiv hizmetleri ve arşiv eğitim çalışmalarına ilişkin dokümanlara, arşiv kaynaklarının korunması ve uluslararası işbirliği üzerine çalışmalara, ilgili alanlarda derneklere, alanda gerçekleştirilen ya da gerçekleştirilecek konferanslar ve bilimsel toplantılara ilişkin bilgilere ulaşmak mümkündür. Yine belge ve arşiv çalışmalarına yönelik güncel sorunlar ve tartışmalar portal aracılığıyla izlenebilmektedir (UNESCO Communication, Information, and Informatics Sector, 2005).

\section{Avrupa'da Belge ve Arşiv Çalışmalarına Yönelik Geliştirilen Uygulama ve Standartlar}

Bu bölümde Avrupa Kıtasında belge ve arşiv işlemlerinde standartlaşma sağlamak amacıyla geliştirilen uygulama modelleri ve standartlara ilişkin bilgiler verilmektedir. İlgili çalışmaların bir kısmı doğrudan AB'nin çeşitli organlarınca da desteklenmiştir. Ủygulama modelleri ve standartlar, belge ve arşiv alanında faaliyet gösteren Avrupa kökenli dernekler, ulusal arşivler ve ortak girişimlerce yürütülen çalışmaların sonucu ortaya çıkmıştır. Uygulama modelleri belgelerin üretiminden nihai ayıklanmasına kadar gerekli işlemleri tanımlarken standartlar belge ve arşiv kaynaklarının tanımlanması, düzenlenmesi ile elektronik ortamda belge ve arşiv çalışmalarına yönelik ilkeleri ortaya koymaktadır. Belge ve arşivcilik alanlarında geliştirilen ve çalışma içerisinde tanıtılan toplam dört adet standart, uluslararası çalışmaların bir parçası olarak ortaya çıkmışır.

Uluslararası Arşiv Konseyi (International Council on Archives, ICA) ve Çalışmaları

1948 tarihinde Paris'te kurulan ICA, uluslararası düzlemde belge ve arşivcilik alanında faaliyet gösteren kuruluşlar kadar, farklı ülkeleri de bir araya getiren bir oluşumdur. ICA şu anda 190 ülkeyi içine alan 1400'ü aşkın üyeye sahip küresel bir arşiv organizasyonu konumundadır. Arşivcilik alanında kurulmuş bir sivil toplum kuruluşu olmasına karşın, güncel değere sahip belgelerin korunması üzerine çalışmaları ile uluslararası belge yönetimi alanında oldukça kapsamlı çalışmalar yürütmektedir. ICA içerisinde oluşturuIan En İyi Uygulama ve Profesyonel Standartlar Komitesi (Committee on Best Practices and Professional Standards), belge yönetimi alanında teknik rehberler ve uygulamalar geliştirmektedir (International Council on Archives [ICA], 2006a, 2006b). 
ICA, belge ve arşiv alanında Avrupa kökenli köklü bir dernek olarak, uluslararası uygulama ve projelere desteğiyle dikkat çekmektedir. 90'lı yıllara kadar geleneksel yaklaşımları savunduğu dile getirilen ICA, özellikle 90'lı yıllarla birlikte belge yönetimi ve elektronik belgeler üzerine çalışmalarıyla ön plana çıkmıştır. ICA arşivcilik, belge yönetimi ve elektronik belgeler üzerine kendi bünyesinde oluşturduğu uzman komiteler çerçevesinde çalışmalar yürütmektedir. Kanada Ulusal Arşivinde görevli John McDonald başkanlığındaki komiteler, ICA'nın uzun dönem savunduğu geleneksel belge ve arşiv yönetimi yaklaşımları yanında, güncel gereksinimler doğrultusunda elektronik ve basılı belgeler üzerine projeler geliştirmeye yönelmektedir. Bu komiteler arasında CECR, önemli bazı çalışmalar yürütmüş ve (MacKenzie, 1999 , s. 32) bu konuda bir dizi program geliştirmiştir. ICA bünyesinde yer alan ülke ya da bölgeleri içine alan geniş bir alanda, ulusal arşivlere yönelik elektronik belge koruma uygulamaları geliştirmektedir. Bu çalışmalar 1997 yılında ICA tarafından elektronik belge yönetimi üzerine yayımlanan rehbere dönüştürülmüştür. Rehber aşağıdaki genel ilkeleri ortaya koymaktadır.

> Arşivler, arşiv değeri taşıyan elektronik belgelerin üretimi ve saklanması dahil, yaşam döngüsü içerisinde yer aldıkları her aşamada etkin rol almalıdırlar.

$>$ Arşivler, belge işlemlerinin özgün, güvenilir ve korunaklı ortamlarda gerçekleştirilip gerçekleştirilmediğini denetlemelidirler.

- Arşivler elektronik belgelerin düzenlenmesi ve kontrolü çalışmalarını yönlendirmek durumundadırlar.

- Arşivler, arşivsel değere sahip elektronik belgelerin erişilebilirliği ve anlaşılabilirliğini artırmaya yönelik gerekli çalışmaları başlatmalıdırlar.

Komite çalışmalarının özellikle elektronik ortamda üretilen ya da kullanılan belgelerin özgünlüğü, güvenilirliği ve korunmasına yönelik ilkeler oluşturmada yoğunlaştığına değinilmektedir (MacKenzie, 1999, s. 32).

Ingiliz Ulusal Arşivi (UK Public Records Office) Tarafından Gerçekleştirilen Çalışmalar

İngiliz Ulusal Arşivinin elektronik ve basılı belgeler için, profesyonel kişilerin kullanımına yönelik oluşturduğu dokümanlar, alanında uluslararası kullanım değerine sahip rehberler olarak algılanmaktadır (Cain, 2002, s. 14). İngiliz Ulusal Arşivi tarafından geliştirilen rehberler dizisi, elektronik belge yönetiminin işlevsel gereksinimlerini ortaya koymak ve gerekli üst veri standartlarını tanımlamak için 1999 yılında hazırlanmıştır. 2002 yılında gözden geçirilen rehberler, belge yönetimi çalışmalarının üretim aşamasından başlayarak son ayıklamaya kadar her aşamada tanımlamayı ve uygulama modeli oluşturmayı hedeflemektedir (Public Records Office [PRO], 2002). Geliştirilen 
rehberler serisi, belge yönetimi alanında çalışmalara ışık tutacak nitelikte ve uluslararası kullanım değeri taşıyan oldukça önemli bilgiler içermektedir (Cain, 2002, s. 14).

Arşiv Kaynaklarının Tanımlanmasına Yönelik Uluslararası Standart (General International Standard Archival Description; ISAD(G)

Uluslararası bir standart olarak ISAD(G)'nin ortaya çıkışı, ICA'nın 1990'da oluşturduğu komisyonlara dayandırılmaktadır. 1990 yılında ICA Arşivsel Tanımlama Komisyonu (Commission on Archival Description)'nu kurmuştur. Komisyon çalışmalarını 1994 yılına kadar sürdürmüş ve bu tarihte ISAD(G) standardının ilk taslağını yayımlanmıştır. ISAD(G) genel olarak, arşiv kaynaklarının erişilebilirliğini artırmak için, ilgili belgelerin içeriğini ve kapsamını tanımlama amacına yönelik olarak geliştirilmiştir. Standart arşiv kaynaklarını örnekler vererek, kısa ve açık bir biçimde tanımlamaktadır (General International Standard Archival Description [ISAD(G)], 2000; Shepherth ve Pringle, 2002, s. 19). ICA tarafından 1999 yılında gözden geçirilen ISAD(G), arşiv kaynaklarının tanımlanması üzerine alanda tek ve en önemli çalışma niteliğini korumaktadır. Elektronik ve elektronik olmayan belgelerin tanımlanması, düzenlenmesi ve korunmasına yönelik geliştirilen sistemlerin birbirlerinden çok faklı uygulamalar gerektirmediği, genel olarak elektronik ve elektronik olmayan belgelerin aynı yöntem ve tekniklerle ele alınması gerektiği standart içerisinde ortaya konulmaktadır (MacKenzie, 1999, s. 32). $\operatorname{ISAD}(\mathrm{G})$ 'nin ikinci baskısı Ağustos 2000'de yayımlanmıştır. ISAD(G) genel olarak yedi bölümde tanımlanmış 26 alandan oluşmaktadır. Bu bölümler:

$>$ Tanımlama alanı

> Kapsama alanı

$>$ İçerik ve yapı (structure) alanı

$>$ Erişim koşulları ve kullanım alanı

$>$ ilişkili materyaller alanı

$>$ Notlar alanı

> Tanımlama kontrol alanından oluşturmaktadır.

ISAD $(G)$, arşivlerde erişim araçlarının kapsaması gereken bilgiler için bir çerçeve sunmaktadır. Standart, belgelerin ve belgelerde yer alan bilgilerin içerik ve konusal önemini doğrultusunda, içerik bilgilerinin korunması ve özgünlük koşullarını tanımlamasını amaçlamaktadır (ISAD(G), 2000).

Anonim Organlar, Kişiler ve Aileler Için Uluslararası Standart Arşiv Otorite Belgeleri (International Standard Archival Authority Records for Corporate Bodies, Persons and Families: ISAAR (CPF)

Arşiv kaynaklarının tanımlanmasında referans alınan bilgiler, ICA tarafından 1996 yılında oluşturulan Anonim Organlar, Kişiler ve Aileler İçin Uluslararası 
Standart Arşiv Otorite Belgeleri (International Standard Archival Authority Records for Corporate Bodies, Persons and Families; ISAAR(CBF)'ye dayandırımaktadır. ISAAR(CBF) kapsamında otorite dosyaları, kontrollü sözlük ve gömüler yer almaktadır. ISAAR (CPF), ICA içerisinde Kanada'nın da dâhil olduğu uluslararası komitelerin çalışmaları sonucu hazırlanmıştır. Alanında tek standart olarak kabul edilmektedir. Bu standardın öncelikli amacı, arşiv belgelerinin tanımlanmasında doğrudan sorumluluğu olduğu düşünülen kişiler, aileler ya da kurumları kapsayan, otorite arşiv kaynaklarının oluşturulmasını sağlamaktadır. Standart genel olarak üç bölümü vardır (International Council on Archives [ICA], 1996; Shepherth ve Pringle 2002, s. 19).

1- Otorite kontrol alanı: Otorite girişlerini yaratmak ve belgenin özgünlüğünü ortaya koymak için sorumlulukları ortaya koymaktadır.

2- Bilgi alanı: Otorite girişlerde yer alan kişiler, aileler ya da kurumların tanımlanmasını kapsamaktadır.

3- Notlar alanı: Otorite belgelerinin nasıl oluşturulacağının saptanmasına ilişkin bilgiler yer almaktadır (ISAAR, 1996).

Arşiv Erişim Araçlarına Yönelik Kodlama Standardı (Encoded Archival Finding Aids ya da Encoded Archival Description - EAD)

Elektronik belgelerin yaygınlaşmasıyla, farklı ortamlardaki bilgi ve belge transferinin ciddi bir soruna dönüştüğüne değinilmektedir. Elektronik ortamda üretilen bilgi kaynaklarına yönelik yapısal ve içerik sorunları ile bu kaynakların gelecekteki kullanım değerini saptama ihtiyacı EAD'nin çıkış noktasını oluşturmuştur. Kısa adı EAD olan Arşiv Erişim Araçlarına Yönelik Kodlama Standardı, 1998 yılında UNESCO'nun RAMP çalışmaları kapsamında ICA ile birlikte başlattığı bir projenin ürünüdür. Proje genel olarak elektronik ortamda giderek artan miktarda oluşturulan belgelere yönelik erişim araçlarının geliştirilmesine odaklanmıştır. Proje ile elektronik ortamda belgelerin korunması ve erişimi sorunlarını gidermek için, gereksinim duyulan kodlama unsurlarının ortaya konulması amaçlamıştır. EAD, makinece okunabilir formatta üretilen envanterler, kütükler, dizinler ve diğer arşiv erişim araçları için genel kabul gören kodlama standardı olarak bilinmektedir. Geliştirilen tanımlama unsurlarının ISAD(G) ve ISAAR (CPF) ile uyumlu olduğuna değinilmektedir. Proje 2003 yılında tamamlanmıştır (UNESCO, 2003).

EAD arşiv kaynaklarının değişimi konusundan günümüzde en popüler format olarak kabul edilmektedir. Standardın gelişmiş dizinleme ve erişim olanakları yanında, arşiv kaynaklarının taranmasına (navigation) sağladığı destekle ön plana çıktığına değinilmektedir. EAD formatının yazııım, donanım ve işletim sistemindeki farklıılılara karşın bütünleşik kullanımlara uygun olduğu belirtilmektedir (UNESCO, 2003; Shepherth ve Pringle, 2002, s. 19). 
MoReq Elektronik Belge Yönetimi Model Gereksinimi (Model Requirements for Electronic Records Management)

MoReq Projesi, Avrupa Komisyonu İdareciler Arasında Veri Değişimi İnisiyatifinin (Interchange of Data between Administration Initiative (IDA) uzantıSI olarak Cornwell Affiliates adlı kuruluşun çalışmaları sonucu 1999 yılında başlamış, zamanla kendi adında bir standarda dönüşmüştür. İnisiyatif içerisinde Almanya, Fransa, Hollanda, Ingiltere, İtalya, Kanada ve Portekiz yer almaktadır (Cain, 2003: s. 54). MoReq'in çıkış noktası olarak, özellikle 90'ı yıllarla birlikte ABD'nin bilgi teknolojisi alanında attığı adımlara karşın Avrupa Birliği'nin bu alanda yetersiz kalması gösterilmektedir. Bununla birlikte IDA-MoReq Projesi, AB ülkelerinde elektronik belgelerin yönetimine dönük problemleri aşmak için bir model olarak tasarlanmıştır. Bu modelden özel ve kamu kesiminde yer alan kurumlar yararlanabilmektedirler. Her ne kadar AB çerçevesinde geliştirilen bir proje gibi görülse de, uluslararası kullanıma yönelik geliştirilmiştir. MoReq'in özellikle elektronik belgelerin yönetimi için sistem gerekliliklerinin tanımlaması aşamasında kullanılması öngörülmektedir (Interchange of Data between Administration [IDA], 2001).

MoReq genel olarak elektronik belgelerin yönetimi için gerekli sistemlerin tasarımı, seçimi ve kontrolü amacıyla 134 sayfalık rehber niteliğinde bir doküman hazırlanmıştır. Bu doküman içerisinde uzun dönemli belge programlarının bir parçası olarak, elektronik olmayan belgeler için de sınıflama şemaları, belge kontrol, güvenlik, saklama ve ayıklama ile belge erişim sistemlerine yönelik yaklaşımlar ve ölçütler yer almaktadır. MoReq kamu kesiminden özel sektöre kadar çok çeşitli alanlarda çalışmalarını yürüten kuruluşlara için belge yönetimi alanında çözüm önerileri sunmayı amaçlamaktadır (Cain, 2002, s. 14; IDA, 2001).

\section{AB Sürecinde Ülkemizde Belge Yönetimine İlişkin Mevcut Durum}

1963 yılında AET ile Türkiye arasında imzalanan Ankara Antlaşması ile başlayan Türkiye-AB ilişkileri, 3 Ekim 2005 tarihinde Lüksemburg'da tam üyelik müzakerelerini başlatılması kararı ile yeni bir boyut kazanmıştır. (Türkiye Avrupa Birliği Karma Parlamento Komisyonu, 2006). Halen tarama sürecinin devam ettiği Türkiye-AB ilişkilerinde ekonomik, sosyal ve siyasal uyum sürecinin, geçmişte olduğundan daha zorlu tartışmalara zemin oluşturacağı üzerinde ısrarla durulan bir konudur (Türkiye Avrupa Birliği Karma Parlamento Komisyonu, 2006; Gümrükçü, 2002). Öte yandan çok yönlü işbirliği ve uyum süreci olarak değerlendirilen $A B$ yolunda, ülkemizde mevcut uygulama ve düzenlemelerin gözden geçirilmesi ve yeni koşullar çerçevesinde gerekli düzenlemelerin, tam üyelik süreci boyunca yapılması gerekli görülmektedir. AB süreci ülkemizde çeşitli alanlarda değişimin yarattığı sorunları beraberinde getirirken, ortak çalışma alanlarında sağlanan 
olanaklar, $A B$ çerçevesinde geliştirilen uygulama ve projelerin bir parçası olma şansı ciddi olarak değerlendirilmek durumundadır. Önceki bölümlerde yer alan belge ve arşiv sistemlerine yönelik değerlendirilen çalışmaların da bu kapsamda ele alınması gerekmektedir. Bilgi teknolojilerin bir parçası olarak görülen elektronik belge yönetimi uygulamaları çerçevesinde gerçekleştirilen çalışmalar belge yönetiminin geleceğine ışık tutacak niteliktedir. Kültürel mirasın bir parçası olarak değerlendirilen arşivlerden ortak yararlanma ve erişime dönük geliştirilen projeler, belge ve arşiv profesyonelliğine yönelik uygulama modeli sunan standartlar ve rehberler de dikkatle ele alınmak ve değerlendirilmek durumundadır. Yine ilgili alanda devam etmekte olan çalışmalara katılmak ve ortak projelere yönelmek ülkemiz için önemlidir

Çalışmanın bu bölümünde ele alınan, $A B$ uyum süreci ile birlikte yeniden yapılanma sürecinin bir parçası olarak değerlendirilen, ülkemizde belge ve arşiv çalışmalarına yönelik geliştirilen düzenlemeler ve uygulamaların da önemli olduğu düşünülmektedir.

Ülkemize belge ve arşiv çalışmalarına yön veren temel düzenleme; 4 Ekim 1988 tarihinde yayımlanan "Muhafazasına Lüzum Kalmayan Evrak ve Malzemenin Yok Edilmesi Hakkında KHK'nin Değiştirilerek Kabulü Hakkında Kanun"dur. 16 Mayıs 1988 tarihli "Devlet Arşiv Hizmetleri Hakkında Yönetmeliktir" ise kurumsal belge işlemlerine yönelik bir uygulama modeli sunmaktadır. Her iki düzenlemeye ek olarak, değişen koşullar çerçevesinde belge ve arşiv hizmetlerinde görülen gereksinimleri karşılayabilmek için çeşitli düzenlemeler gerçekleştirilmiştir. Bu düzenlemelerin, bilgi ve belge işlemlerinin değişen koşullar çerçevesinde yeniden yapılandırılması ve ilgili diğer unsurlarla eşgüdümleşmesi, elektronik ortamda bilgi ve belge işlemlerinin gerçekleştirilebilmesine ortam hazırlanması ile $A B$ ve benzeri uluslararası kurumlarla uyum sürecinin bir parçası olduğu için ortaya çıktığı düşünülmektedir. Bu düzenlemeler kronolojik düzende aşağıda verilmektedir:

1. 'Ayıklama ve İmha İşlemlerinde DAGM'nün Uygun Görüşünün Alınması, Yıllık Arşiv Faaliyet Raporunun Aksatılmadan Gönderilmesi, Yönetim Kurulu ve Benzeri Kararlar İle Eski Harfli Türkçe Arşiv Malzemesinin Bekletilmeden Devlet Arşivlerine Devri”. Başbakanlık Genelgesi, Sayı: 18975, 20 Ekim 1998.

2. "Devlet Arşiv Hizmetleri Hakkında Yönetmelikte Değişiklik Yapılmasına Dair Yönetmelik”. T.C. Resmi Gazete, Sayı: 24487, 8 Ağustos 2001: 95-100.

3. "Bilgi Edinme Hakkı Kanunu". T.C. Resmi Gazete, Sayı: 25269, 24 Ekim 2003: 1-8.

4. "Elektronik İmza Kanunu". T.C. Resmi Gazete, Sayı: 25355, 23 Ocak 2004: 1-8. 
5. "Bilgi Edinme Hakkı Kanununun Uygulanmasına İlişkin Esas Ve Usuller Hakkında Yönetmelik". T.C Resmi Gazete, Sayı: 25445, 27 Nisan 2004: 1-13.

6. "Resmi Yazışmalarda Uygulanacak Esas ve Usuller Hakkında Yönetmelik". T.C. Resmi Gazete, Sayı: 25658, 2 Aralık 2004: 5-26.

7. "Standart Dosya Planı İle İlgili Başbakanlık Genelgesi". T.C. Başbakanlık Personel ve Prensipler Genel Müdürlüğ̈̈’, Sayı: 320-3802, 24 Mart 2005: 1-55.

Bu düzenlemelere ek olarak henüz yasallaşmasa da, Başbakanlık Devlet Arşivleri Genel Müdürlüğü (DAGM) tarafından DAGM'nin Kuruluş ve Görevleri ile Devlet Arşiv Hizmetleri Hakkında Kanun Tasarısı ve Ulusal Bilgi Güvenliği Teşkilatı ve Görevleri Hakkındaki Kanun Tasarısı Taslağı sonuçlandırılmış (Elektronik Belge Yönetimi Sistem Kriterleri Referans Modeli. 2005, s. 88) ve 4 Mayıs 2006 tarihinde TBMM'de Milli Eğitim Komisyonundan geçerek yasallaşma süreci hız kazanmışıı (Reuters Haber Ajansı, 2006).

\section{Elektronik Belge Yönetimi Sistem Kriterleri Referans Modeli (EBYSKRF)} Elektronik Belge Yönetimi Sistem Kriterleri Referans Modeli (EBYSKRF), Marmara Üniversitesi ve DAGM'nün birlikte yürüttüğü bir proje kapsamında Prof. Dr. Hamza Kandur tarafından 2005 yılında hazırlanmıştır. Projenin amacı, "kamu kurumlarında üretilen ve/veya üretilmesi muhtemel elektronik belgelerin arşiv belgesi niteliğinin korunabilmesi için gerekli standartların belirlenmesi" olarak saptanmıştır. Proje kapsamında ortaya konulan referans modelinde aşağıdaki konular ele alınmaktadır.

- Elektronik belgenin nitelikleri: Elektronik belgede bulunması gereken diplomatik özelliklerin belirlenmesi, elektronik belgelerin hukuki geçerliliklerinin sağlanması için alınması gereken önlemler, elektronik imza ve mühür sistemlerinin uygulanması için gerekli sistem alt yapısının tanımlanması.

> Yönetim sorumluluklarının belirlenmesi: Elektronik belgelerin üretim, depolama, saklama, koruma ve devlet arşivlerine transferiyle yükümlü kamu kurum ve kuruluşlarına ait yönetim sorumluklarının belirlenmesi.

> Elektronik belge yönetimi sistem gereklilikleri: Belge yönetimi ve özellikle elektronik belge yönetimi sistemi kuracak olan kamu kurum ve kuruluşları için gerekli sistem gereksinimlerinin tanımlanması. Bulgular arasında arşivcilik biliminin gerektirdiği teknik ve uygulamaların yanı sıra, belge yönetim sisteminin elektronik ortamda yürütülebilmesi veya elektronik belgelerin yönetilebilmesi için gerekli gereksinimlerin de tanımlanması. 
> Kamu kurum ve kuruluşların bilgi sistemleri envanteri: Devlet arşivlerinin yetki kapsamında bulunan kurum ve kuruluşlarda mevcut bilgi sistemlerinin envanterinin çıkarılarak, bu sistemlerde üretilen elektronik belgelerin uygunluk testlerinin yapılması (Elektronik Belge Yönetimi Sistem Kriterleri Referans Modeli, 2005).

Elektronik belge yönetimi sistemlerinin tasarlanması, çevresel unsurlarla birlikte tanımlanması, bu sistemlerle uyumlu yazılım ve donanım olanaklarının belirlenmesi, elektronik bilgi ve belge sistemleri için ölçütlerin saptanması, belge yönetimi çalışmalarına yönelik politika ve izleklerin oluşturulmasında hazırlanan modelin son derece önemli olduğu görülmektedir. Model içerisinde sistem ölçütleri yedi bölümde ele alınmaktadır. 1.bölüm: Genel olarak sistem ölçütleri hakkında tanımlama bilgilerine; 2. bölüm: Dosya tasnif planlarının oluşturulması, tanımlanması ve yönetimine; 3. bölüm: Saklama planları, belge hiyerarşisi, saklama ölçütleri, saklama süreleri, tasfiye işlemleri ve uyuşmazlıkların çözümlenmesiyle ilgili bilgilere; 4. bölüm: Elektronik belgelerin kayıt işlemlerine ayrılmıștır. 5. bölüm: Elektronik belge yönetim sistemleri kullanım özelliklerini, 6 . bölüm: Erişim hakları ve güvenlik başlığı altında uygulama modelleri ve gerekli ölçütleri tanımlamaktadır. 7. bölümde ise sistem tasarımı ve yönetimi ele alınmaktadır.

Model içerisinde ikinci aşamada belge ölçütleri verilmektedir. Bu kapsamda belge özellikleri, belge yönetimi, elektronik olmayan sistemlerle uyumluluk ve sayısal görüntüleme sistemleri başlıkları altında gerekli ölçütler ve bilgiler sunulmaktadır.

Modelin üçüncü aşamasında EBYS, içerisinde yer alacak üst veri elemanlarına yönelik ölçütler ve gerekli bilgiler tanımlanmaktadır. Bu bölümde üst veri modülünün tasarımından, sistem kullanımı üst veri elemanlarına kadar "zorunlu" ve "seçmeli" unsurların yer aldığı son derece kapsamlı bilgiler bulunmaktadır.

ICA ve Avustralya ve İngiliz Ulusal Arşivlerinin çalışmaları, MoReq Modeli, DoD 5015.2 Standardı, INTARPARES Projesi, ISO 15489 Standardı, ANSI/ARMA Standartları... vb. uluslararası çalışmalarla uyumlu olarak hazırlanan modelin, ülkemizde elektronik ortamda belge yönetimi üzerine, uluslararası uygulama ve standartlarla uyumlu ve eşgüdümlü çalışmaların yürütülebilmesi noktasında yararlı olacağı düşünülmektedir.

\section{Değerlendirme ve Sonuç}

Avrupa ülkelerindeki kuruluş ve derneklerin çalışmaları ile $A B$ çerçevesinde belge yönetimi üzerine geliştirilen uygulama modelleri, standartlar ve ortak girişimler genel olarak değerlendirildiğinde, $A B$ genişleme sürecinin ilgili çalışmaları olumlu yönde etkilediği açıkça görülmektedir. Birbirlerinden 
oldukça farklı sosyo/ekonomik ilişkilere sahip ülkelerin, kendi kimliklerini koruyarak ortak zeminlerde birlikte çalışmalara yönelmesi, beraberinde son derece güçlü bir sinerji yaratmaktadır. Bu durum küreselleşme sürecinin aslında ne denli önemli olduğunun kanıtı olarak da değerlendirilebilir. Teknoloji üretme, ürün ve hizmetlerde kalite ve verimliği sürekli kılma, daha saydam ve hızlı işleyen idari mekanizmalar oluşturma, bilginin serbest dolaşımı, kolay ve hızlı erişimi ve paylaşımı üzerine yaklaşımlar geliştirme, bugün küresel bir güç olan AB'nin öncelikli hedefleri arasında sıralanmaktadır. Bu hedefler doğrultusunda meslek dernekleri ile koordineli çalışmalara imza atan AB bilgi çağına, Kuzey Amerika ve Asya'da yükselen pazarlarla bir taraftan rekabet ederken, diğer taraftan küresel işbirliğini daha geniş alanlara yaymaya yönelmektedir. Bu çerçevede gelişmeler değerlendirildiğinde, hantal bürokratik sistemlerin yeniden yapılandırılması ve ortak kalite ölçütlerinin belirlenerek verimliliğin yükseltilmesine dönük çözümlemeler, iş süreçlerinin ve kurumsal iletişimin etkinleştirilmesi ve elektronik ortama aktarılmasına yönelik girişimler belge ve arşiv uygulamalarıyla birlikte ele alınmak durumundadır. Bununla birlikte elektronik ortamda veri güvenliğinin sağlanması ve standartlaşma çalışmaları, ortak değerlerin paylaşımı ve değerlendirilmesi üzerine yaklaşımlar doğrudan belge ve arşiv yönetimi alanlarıyla ilişkili görülmektedir. Bu çözümlemeyi destekleyen verileri çalışma içerisinde ortaya konulan gelişmelerde görmek mümkündür. Avrupa'da belge yönetimi alanında çalışmalar 90'lı yıllardan sonra yoğunlaşmıştır. Çalışma içerisinde değinilen ve 90'ların başında ortaya çıkan DLM Forumu konuya en güzel örneklerden biridir. Amacı, Avrupa'da belge ve arşiv üzerine çalışmalar yürüten kişi ya da kurumları bir araya getirmek olan Forum, zamanla çekim merkezi haline dönüşmüştür. DLM Forum günümüzde, bünyesinde iki farklı süreli yayının çıkartıldığı, belge ve arşiv uygulamalarının Avrupa boyutunda standartlara dönüştürüldüğü, ortak girişim ve projelerin geliştirildiği, belge ve arşiv uygulamalarına dönük son derece zengin bilgi birikiminin oluştuğu güçlü bir kaynak konumundadır.

Bu noktada bir uluslararası arşiv derneği olan ICA'nın, 90'lı yıllardan itibaren Avrupa boyutunda belge ve arşiv yönetimi uygulamalarının geliştirilmesi, standartlaşma ve ortak girişimlere desteğinin altını çizmek gerekir. $\operatorname{ISAD}(\mathrm{G})$, ISAAR, EAD standartlarının geliştirilmesi ICA'nın çalışmalarının ürünüdür. ICA, ilgili $A B$ kurumlarıyla yakın ilişkiler ve ortak girişimler gerçekleştirerek, Avrupa'nın belge ve arşiv alanında da düşünce, kuram ve standartlar üreten bir noktaya gelmesine katkı sağlamaktadır.

$A B$ için çok kültürlü ve çok disiplinli projeler vazgeçilmez öneme sahiptir. İlgili çalışma ve projelere AB'nin sağladığı destek, bu önemin en açık kanıtı olarak görülebilir. Belge ve arşiv alanında zaman zaman ICA ve UNESCO gibi uluslararası kurumların da desteğini alan projeler içerisinde iki farklı yönde eğilim dikkat çekmektedir. Elektronik belge yönetimi ve arşivleme 
üzerine ortak çalışmalar, teknolojik gelişmeler doğrultusunda gereksinimleri karşılamaya yönelirken, kültürel mirasın parçası olarak görülen arşivlere ortak erişim ve bilgi havuzu oluşturma, Avrupa ortak kimliğinin oluşturulması ve paylaşımını amaçlamaktadır. Çalışma içerisinde değinilen bu projelerin önümüzdeki yıllarda artarak devam edebileceği öngörülebilir.

Ülkemizde, özellikle $A B$ perspektifinin daha da belirginleşmesinin ardından, her alanda olduğu gibi belge ve arşiv çalışmalarını ilgilendiren konularda da son derece hızlı gelişmelere tanık oluyoruz. Bilgiye serbest erişim ve bilgi edinme hakkı konusundaki yasal düzenlemelerin gerçekleştirilmesi, elektronik ortamda belge yönetimine dönük Elektronik İmza Kanunu yakın tarihlerde çıkarılmış olması önemli gelişmeler arasındadır. Yine DAGM tarafından belge ve arşiv yönetimine dönük hazırlanan kanun tasarıları ve son olarak elektronik belgeler, bu belgelerin elektronik ortamda etkin yönetimi ve gerekli yazılım programlarına dönük hazırlanan Referans Modeli bu gelişmelere örnek olarak verilebilir. Çalışma kapsamında ayrıntılarına inilmeden verilen uygulamaların, belge ve arşiv alanında uluslararası düzenlemeler ve $A B$ normlarıyla bütünlük içerisinde ele alındığı bilinmektedir. Ancak çalışmaların ülke perspektifinin ötesinde ortak girişimlere dönüştürülmesi öncelikle ele alınması gerekli görülmektedir. Bunun için, ilgili kurumlar ve örgütlerle ortak çalışma zemininin aranması, geliştirilen ya da geliştirilmekte olan girişim, proje, uygulama ve standartlaşma çalışmalarına dâhil olunması gerekmektedir. AB'nin ilgili alanda birikiminin ülkemizde belge ve arşiv yönetimi alanındaki çalışmalara katkı sağlaması ne kadar olasıysa, ülkemizin yüzyıllara dayanan birikiminin bu noktada o denli önemli olacağı öngörülmektedir. Böylece sadece tüketen ve örnek uygulamaları hayata geçiren değil, yeni uygulama modelleri ile bilgiyi üreten ve yayılmasına katkı sağlayan noktaya ulaşabiliriz. AB çerçevesinde oluşan küresel koşulların bir parçası olarak ülkemizin her alanda olduğu gibi, belge ve arşiv yönetimi üzerine çalışmalarda da çokuluslu girişim ve projelerin ortağı olması, ulusal kalkınmamızın son derece önemli bir yönü olarak değerlendirilmektedir.

\section{Kaynakça}

Abraham, T. (1995-2006). Repositories of primary resources. 14 Mart 2006 tarihinde http://www.uidaho.edu/special-collections/Other.Repositories.html adresinden erişildi.

Akçeken, E. (2003). Avrupa Birliği uyum sürecinde Türkiye'deki enformasyon hizmetleri. Yayımlanmamış bilim uzmanlığı tezi. Hacettepe Üniversitesi, Ankara.

Avrupa Birliği. (1995). Avrupa Birliği nedir? 6 Şubat 2006 tarihinde Avrupa Birliği Türkiye Delegasyonu sitesinden erişildi: http://www.deltur.cec.eu.int 
Bradscher, J. G. (1988). History of archival administration. Managing archives and archival institutions içinde James Gregory Bradsher (Ed.). Chicago: The University of Chicago Press.

Cain, P. (2002). Model requirement for the management of electronic records (MoReq): A Critical Evaluation. Records Management Journal, 12 (1): 14-18.

Cain, P. (2003). MoReq: The Standard of the Future. Information Management Journal, 37 (2): 54-59.

Central European University. (1995-2005). Open society archives. 13 Ocak 2006 tarihinde http://www.osa.ceu.hu adresinden erişildi.

Cook, M. (1986). The Management of information from archives. London: Aldershot.

Cook, M. (1993). Information management and archival data. London: Library Association Pub.

Coşkun, E. (2001). Bütünleşme sürecinde Avrupa Birliği ve Türkiye. İstanbul: Cem Yayınları.

DLM Forum (Donnes Lisibles par Machine). (1999): European citizens and electronic information: the memory of the Information Society (2006). 13 Mart 2006 tarihinde http://europa.eu.int/ISPO/dlm/dlm99/index.htm adresinden erişildi.

Doug, J. (1996). Records management in USA. Records Management Journal, 6 (3): 211-218.

Eden, P. ve John F. (1997). Preservation policies and strategies in British and Records Offices: A survey. Journal of Society of Archivists. 18 (1): 59-70.

Elektronik Belge Yönetimi Sistem Kriterleri Referans Modeli. (2005). Hamza Kandur (Haz.). İstanbul: Devlet Arşivleri Genel Müdürlüğü.

European Archival Network. 9 Ocak 2006 tarihinde http://www.europeanarchival.net/ean/services.htm adresinden erişildi.

Data Protection Act. (1998). 18 Ocak 2006 tarihinde http://www.opsi.gov.uk/acts/acts1998/19980029.htm adresinden erişildi.

European Commission on Preservation and Access. (2004). GRIP: Gateway for Resources and Information on Preservation. 10 Ocak 2006 tarihinde http://www.knaw.nl/ecpa/grip/ adresinden erişildi.

Europe DAMS Project: Digital Archive and Memory Storage (Milano). UNESCO Archives Portal. 13 Ocak 2006 tarihinde http://www.unesco.org/cgi-bin/webworld/portal_archives/cgi/page.cgi?g = Communities\%2FInternational_Co-operation\%2FCooperation_Programmes_and_Projects\%2Findex.shtml;d=1 adresinden erişildi. 
European Union. (2000). Welcome to the eContent Programme. 12 Ocak 2006 tarihinde http://www.cordis.lu/econtent/home.html adresinden erişildi.

European Union Archive Network (EUAN). (2003).13 Ocak 2006 tarihinde http://www.euan.org/ adresinden erişildi.

European Visual Archive (EVA). 13 Ocak 2006 tarihinde: http://www.evaeu.org adresinden erişildi.

General International Standard Archival Description. ISAD(G). (2000). General International Standard Archival Description 2nd Ed. 9 Mart 2006 tarihinde http://www.ica.org/biblio/isad_g_2e.pdf adresinden erişildi.

Gümrükçü, H. (2002). Avrupa Türkiye ilişkilerinin geleceği. 6 Şubat 2006 tarihinde http://www.abhaber.com/belgeler/blg_00034.asp adresinden erişildi.

Interchange of Data between Administration (IDA). (2001). Model Requirements For The Management of Electronic Records (MoReq). 16 Mart 2006 tarihinde http://ec.europa.eu/idabc/servlets/Doc?id=16847 adresinden erişildi.

IFLA/FAIFE: International Federation of Library Association and Institutions (IFLA), Committee on Free Access to Information and Freedom of Expression, (FAIFE). (1998). 12 Ocak 2006 tarihinde http://www.ifla.org/faife/index.htm adresinden erişildi.

INSAR (2002). Proceedings of the DLM Form: European Archival News, Supplement 7. 13 Mart 2006 tarihinde http://europa.eu.int/comm/ secretariat_general/edoc_management/dlm_forum/doc/dlm-proceed 2002.pdf adresinden erişildi.

International Council on Archives [ICA]. (1996). Ad Hoc Commission on Descriptive Standards. ISAAR(CPF): International standard archival authority record for corporate bodies, persons and families : Final ICA approved version. $10 \quad$ Mart 2006 tarihinde http://www.ica.org/biblio/isaar_eng.html adresinden erişildi.

International Council on Archives [ICA]. (2003). Access to Archival Monitoring Project. 13 Ocak 2006 tarihinde http://www.ica.org/news. php?pnewsid=76\&plangue=eng adresinden erişildi.

International Council on Archives [ICA]. (2006a). ICA in brief. 27 Ocak 2006 tarihinde http://www.ica.org/static.php?ptextid=bref\&plangue=eng adresinden erişildi.

International Council on Archives [ICA]. (2006b). Committee on Best Practices and Professional Standards. 31 Ekim 2006 tarihinde http://www.ica.org/body.php?pbodycode=CBPS\&plangue=eng adresinden erişildi. 
MacKenzie, G. (1999). A new world ahead: International challenges for information management. Informational Management Journal, 33 (2): 24-34

Özcan, M. (1999). Avrupa Birliğinde fikri ve sınai haklar. Ankara: Nobel Yayınlar.

Penn, I. A, A. Mordel ve G. Penix. (1994). Record management handbook. Kelvin Smith: Gower.

Public Records Office. (2002). Functional requirements for electronic records management. 9 Mart 2006 tarihinde http://www.nationalarchives.gov. uk/documents/requirementsfinal.pdf adresinden erişildi.

Reuters Haber Ajansı. (2006). Arşiv hizmetlerini düzenleyen tasarı komisyonda kabul edildi. 4 Mayıs 2006 tarihinde http://www.isbank.com.tr/reutershaber-detay.asp?Document_Header=nGOK438372 adresinden erişildi.

Spratt, R. (2003). Records management: the next ten years: Part 3. RDIMS (Records, Documents and Image Management Systems). SEALINES: Newfounland and LABRADOR ARMA Chapter News July/August 2003 31 Ekim 2006 tarihinde http://www.armaterranova.org/pdfs/ 2003JULAUG.pdf adresinden erişildi.

Stephens, D. O. (1998). Data protection in Europe. ARMA Records Management Quarterly, 32 (4): 73-75.

Stephens, D. O. (2001). Megatrends in international records management. Information Management Journal, 35 (4): 66-70.

Shepherth, E. ve Rachael Pringle (2002). Mapping Descriptive Standards Across Domains: A Comparision of ISAD (G) and SPECTRUM. Journal of the Society of Archivists, 23 (1): 17-34.

T.C. Başbakanlık Devlet Arşivleri Genel Müdürlüğü Osmanlı Arşivleri Daire Başkanlığı (2000). Belgelerle arşivcilik tarihimiz (Osmanlı Dönemi) I. Ankara: T. C. Başbakanlık, Devlet Arşivleri Genel Müdürlüğü, Osmanlı Arşivi Daire Başkanlığı Yayın No: 41. Ankara: Başbakanlık Basımevi. 3 Nisan 2006 tarihinde http://www.devletarsivleri.gov.tr/yayin/osmanli/ Arsivciliktarihi/ 00001_arsivciliktarihi.htm adresinden erişildi.

Tulane University. Ready, Net, Go! Archival internet resources. 3 Nisan 2006 tarihinde http://www.tulane.edu/ Imiller/ArchivesResources.html adresinden erişildi.

Türkiye Avrupa Birliği Karma Parlamento Komisyonu. Türkiye-AB Iliş̧kilerinde Önemli Tarihler Kronolojisi. 4 Nisan 2006 tarihinde http://www.tbmm.gov.tr/ul_kom/kpk/trabils.htm adresinden erişildi. 
Türkiye Bilişim Derneği. (2006). E-devlet kavramları el kitabı (2. sürüm). Önder Özdemir. Abdullah Vezir, Cemal Tura... (Derleyenler). 8 Mayıs 2006 tarihinde http://www.kamubib.tbd.org.tr/dokumanlar/3BG.pdf adresinden erişildi.

UNESCO. (1987) ICS Milletlerarası Arşiv Konseyi: Yayımlar. Ankara: T.C. Başbakanlık Devlet Arşivleri Genel Müdürlüğü.

UNESCO. (2002). UNESCO Guidelines for Establishing Digitization Programmes for Libraries and Archives. 8 Mart 2006 tarihinde http://www.unesco.org/webworld/public_domain/projects/digitization.shtml adresinden erişildi.

UNESCO. (2003). Encoded Archival Finding Aids. (EAD). 10 Ocak 2006 tarihinde http://portal.unesco.org/ci/en/ev.php-URL_ID=4973\&URL_DO= DO_TOPIC\&URL_SECTION=201.html adresinden erişildi.

UNESCO. (2004). Legal evidence of electronic records. 17 Mart 2006 tarihinde http://portal.unesco.org/ci/en/ev.php-URL_ID=4975\&URL_DO= DO_TOPIC\&URL_SECTION=201.html adresinden erişildi.

UNESCO. (2005). Cooperation Programs and Projects. 8 Mart 2006 tarihinde http://www.unesco.org/webworld/portal_archives/pages/Communities/Int ernational_Co-operation/Co-operation_Programmes_and_ Projects/index.shtml adresinden erişildi.

UNESCO. Communication, Information, and Informatics Sector. (2005). UNESCO Archival Portal. 3 Nisan 2006 tarihinde http://portal.unesco.org adresinden erişildi.

Waldron, M. (2004). Adopting electronic records management: European strategic initiatives. Information Management Journal, 38 (4): 31-35. 